\title{
Impacts of soil and water conservation practices on soil property and wheat productivity in Southern Ethiopia
}

\author{
Tesfaye Tanto and Fanuel Laekemariam*
}

\begin{abstract}
Background: Soil erosion and nutrient depletion have been the major challenges in Ethiopia that adversely affect soil fertility and crop productivity. With the aim of curbing land degradation problems, efforts are underway on the implementation of soil and water conservation (SWC) practices. This research investigated the effects of SWC practices on soil properties and crop productivity in cultivated lands of Bashe micro-watershed, Wolaita Zone, Southern Ethiopia. Data were collected from five different practices viz. non-conserved land, physical SWC (2 and 5 years age); and physical SWC integrated with biological practices ( 2 and 5 years age).

Results: The result revealed that integrated SWC for 5 years reduced the soil bulk density; and increased soil pH (5.87 to 6.60 ), organic carbon (1.34 to 1.74\%) and available phosphorous ( 8.06 to $25.23 \mathrm{mg} \mathrm{kg}^{-1}$ ) by $12 \%, 30 \%$ and $203 \%$ compared to non-conserved land, respectively. Agronomic analysis also indicted that SWC practices significantly ( $p<0.05$ ) enhanced plant height, tiller formation, spike length, thousand seed weight, biomass, and grain yield of wheat. Integrated SWC for 5 years increased grain yield by $72.8 \%$ than control.

Conclusion: It is concluded that SWC practices have positive impacts on soil and crop productivity of cultivated lands; however, their effect is more pronounced when physical SWC practices are integrated with biological SWC practices and at a longer establishment.
\end{abstract}

Keywords: Crop growth, Fanyajuu, Soil conservation, Soil property, Yield

\section{Introduction}

Land degradation in the form of soil erosion and fertility depletion is a major challenge in the Ethiopian highlands due to its adverse impacts on crop productivity, food security and natural resource conservation (Laekemariam et al. 2016; Teklu et al. 2018; Adimassu et al. 2017). The principal causes are rapid population growth and improper land resources management and utilization which finally declining agricultural productivity (Laekemariam et al. 2016). Erratic and erosive rainfall, steep terrain, deforestation, inappropriate land use, land fragmentation, overgrazing and weak management practices are among the factors that cause land degradation in the country (Osman and Sauerborn 2001). The review paper

*Correspondence: laeke2005@yahoo.com; maedotmeklit@gmail.com College of Agriculture, Wolaita Sodo University, P.O. Box 138, Wolaita Sodo, Ethiopia by Adimassu et al. (2017) indicated that soil loss due to erosion in the Ethiopian highlands is between 42 and $175.5 \mathrm{t} \mathrm{ha}^{-1}$ year $^{-1}$. Other studies on crop fields have also confirmed that declining soil fertility and limited water availability resulted to low crop yields on Ethiopian highlands (Laekemariam et al. 2016; Adimassu et al. 2017; Teklu et al. 2018).

In an effort to curb soil erosion and nutrient depletion, government of Ethiopia (GoE) in collaboration with local community and several donors have been implemented large national soil and water conservation (SWC) program since the 1970s (MOARD 2005). The GoE, since 1980s, has supported rural land rehabilitation through watershed development approach; and management has moved from a focus on physical SWC to the integration of social, economic, and environmental development (MOARD 2005). Welu and Solomon (2015) explained 
that soil bund, fanyajuu bund and deep trench structures are widely implemented physical SWC structures to conserve cultivated land from soil erosion.

Research efforts on the effects of SWC practices demonstrated that they may improve soil physico-chemical properties (e.g. Mekuria et al. 2006; Adimassu et al. 2017; Teklu et al. 2018); reduce soil loss by sediment trapping (Walie and Fisseha 2016); improve crop growth and yield (Walie and Fisseha 2016; Teklu et al. 2018); fodder yield (Kebede 2015) and farmers' income (Amede 2003). Yet, this generalization is coarse and inconsistent as there are different factors influencing the effectiveness of SWC practices. For instance, the potential of SWC practices to restore soil properties and result better yield would be influenced by age of structures (Mekuria et al. 2007; Dulo et al. 2017; Adimassu et al. 2017); integration of physical and biological activities (Fikir et al. 2009; Teklu et al. 2018); type of physical practices (Gachene and Kimaru 2003); and the soil fertility condition of the land at a time when treated with SWC measures. Thus, taking into account of soil-crop-and management type specific information is pertinent for sustainable implementation of soil conservation practices at field, farm and watershed level.

Damot Gale woreda (district) is located in Wolaita Zone, Southern Nation, Nationalities, and People Regional State (SNNPRS) of Ethiopia where soil erosion and soil fertility depletion have been a major problems resulting lower crop yields (DGWFED 2016; Laekemariam et al. 2016, 2018). The mean soil loss on neighboring district (Delbo Wogene micro-watershed, Sodo Zuria district, Wolaita zone) was estimated to be $48.6 \mathrm{t} \mathrm{ha}^{-1}$ year (Abebayehu and Awdenegest 2015). With response to severe land degradation problems, the woreda in support of the government and non-government programs have been implemented watershed based soil conservation practices. Among watersheds, Bashe micro watershed is the one on which SWC activities have been undertaken since 2010 (DGWAO 2016). Fanyajuu type of physical soil conservation practice is commonly implemented on farm lands following SNNPRS recommendation (SNNPRS Agr. 2012). Moreover, to rehabilitate physical conservation biologically and also for other purpose, some farmers on embankments have been growing elephant grass (P. Purpureum), Sesbania sesban (S. sesban), Desho grass (Pennisetum pedicellatum), and peagon pea (Cajanus cajan) (DGWAO 2016). However, information on the effects of SWC practices (alone, integrated and with age of practices) on soil properties and crop productivity has been lacking in Bashe micro watershed. Thus, the main objectives of this study are to explain the effects of SWC practices on (i) soil properties, and (ii) growth and yield of crop.

\section{Materials and methods Description of study area}

The study was conducted in Bashe micro watershed $\left(37^{\circ} 47^{\prime} 37.829^{\prime \prime} \mathrm{E}\right.$ and $\left.6^{\circ} 56^{\prime} 23.7^{\prime \prime} \mathrm{N}\right)$ which is found in Akabilo Kebele, Damot Gale district (Woreda), Wolaita Zone of Southern Ethiopia (Fig. 1). The study area falls within the altitude of 1805-2601 m elevation range that receives an average annual rainfall of $800-1500 \mathrm{~mm}$. The minimum and maximum mean temperature is $18{ }^{\circ} \mathrm{C}$ and $25^{\circ} \mathrm{C}$, respectively (DGWFED 2016). The soil of the area is mainly covered by Nitisols. Damot Gale is the most populated district within Wolaita zone (CSA 2007) where the livelihood of farmers relies heavily on agriculture. Wheat (Triticum aestivum), teff (Eragrostis tef), maize (Zea mays), haricot bean (Phaseolus vulgaris), and field pea (Pisum sativum) are major crops grown in the area.

Total area of Bashe watershed is about 414.9 ha. The slope within watershed varies from 3 to $58 \%$ where majority of crop lands lay between 10 and 20\% (DGWAO 2016). Bashe watershed is characterized by problem of soil erosion, low soil productivity, low fodder supply, and intensive cultivation (DGWAO 2016). Since 2010, with the aim of curbing soil erosion and soil fertility depletion within watershed, efforts are underway on the implementation of physical and biological soil conservation practices.

\section{Treatment selection}

Five different SWC practices were used as treatments in order to study their effects on soil properties and crop yield. These include: non-conserved land, physical soil conservation ( 2 and 5 years old); and physical conservation integrated with biological practices ( 2 and 5 years old). Preliminary field survey within watershed has been done in order to secure a good representation of the treatments having SWC practices of different age. Each practice had three replications in which they are located in the upper, middle and lower part of watershed. Thus, a total of 15 cultivated lands ( 5 practices $\times 3$ replication) were identified for soil and crop data collection.

\section{Soil sampling and laboratory analysis procedure}

Surface soil sample (disturbed and undisturbed) were collected at $0-20 \mathrm{~cm}$ depth (Laekemariam et al. 2016) for determination of soil particle size distribution (PSD), bulk density (BD), soil $\mathrm{pH}-\mathrm{H}_{2} \mathrm{O}$, organic carbon $(\mathrm{OC})$, and available phosphorus (AP). Soil samples were analyzed following standard procedures at Horticoop soil lab, Debre Zeit, Ethiopia. Soil BD was determined by using the core method (Anderson and Ingram 1993). Soil PSD was analyzed by Bouyoucos hydrometer method (Bouyoucos 1951). Soil pH- $\mathrm{H}_{2} \mathrm{O}$ was measured using 1:2.5 soil to water ratio using $\mathrm{pH}$ meter (Van Reeuwijk 


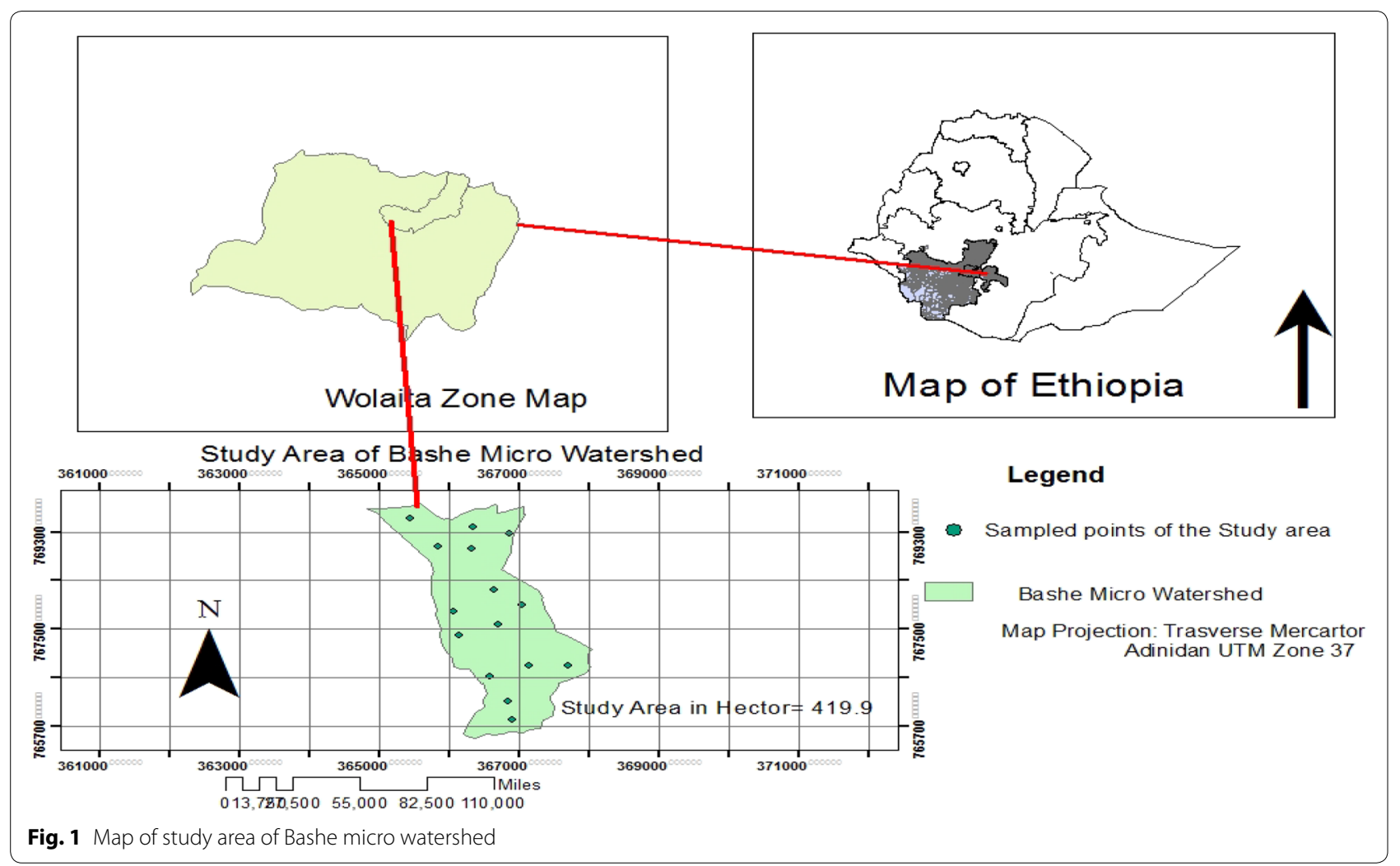

2002). The Walkley and Black method was applied to determine the OC content (Walkley and Black 1934). Available P (Olsen) was measured using sodium bicarbonate extraction solution (Olsen et al. 1954).

\section{Crop data sampling procedures}

Wheat is one of major cereal crop grown in Bashe micro watershed during the main rainy season (June-September). Thus, improved bread wheat (variety 604) that was promoted by woreda extension system was taken as a test crop to evaluate the crop response on above mentioned SWC practices (i.e., treatments). The crop was planted with package of recommendations such as fertilizer [100 kg NPS (19-38-0-7SO $)$ and $100 \mathrm{~kg}$ Urea (46$0-0)$ ], seed rate $\left(125 \mathrm{~kg} \mathrm{ha}^{-1}\right)$, row planting and two hand weeding.

At physiological maturity stage of the crop (November, 2018), a square quadrant with $0.3 \mathrm{~m} \times 0.3 \mathrm{~m}\left(0.09 \mathrm{~m}^{2}\right)$ size was randomly assigned to three random spots (top, middle and bottom) of each crop land that was identified for soil data collection. The crop within each quadrant was harvested to record growth, yield and yield component parameters following standard agronomic data collection procedures. Plant height $(\mathrm{cm})$ was determined from the base to the tip of the spike (awns excluded from 10 randomly selected plants). Spike length $(\mathrm{cm})$ is part of wheat plant which is the length occupied by seed. It is measured from 10 randomly selected plants. Number of tillers was determined by counting the plants from each quadrant $0.3 \mathrm{~m} \times 0.3 \mathrm{~m}\left(0.09 \mathrm{~m}^{2}\right)$, and then converted into $\mathrm{m}^{2}$. Number of productive tillers was determined by counting all spikes producing seeds of each quadrant then converted into $\mathrm{m}^{2}$.

Above ground dry biomass $\left(\mathrm{t} \mathrm{ha}^{-1}\right)$ was taken by harvesting and measuring sun dried weight from each quadrant and then converted to $t \mathrm{ha}^{-1}$. Grain yield $\left(\mathrm{t} \mathrm{ha}^{-1}\right)$ was measured after threshing the seed yield from each quadrant and then converted to tons per hectare after adjusting to moisture content of $12.5 \%$. Straw yield $\left(\mathrm{t} \mathrm{ha}^{-1}\right)$ was obtained as the difference of the total above ground plant biomass and grain yield of plants of randomly selected quadrat area then converted to ton per hectare. Thousand grain weights (g) was determined based on the weight of 1000 grain sampled from the grain yield of each treatment by counting using weight sensitive balance and weighed with electronic balance.

\section{Statistical analysis}

The effects of SWC practices on soil properties and wheat yield were evaluated using different statistical methods. Analysis of variance (ANOVA) was performed for crop data using Statistical Analysis System (SAS Institute Inc 
2008). Soil data was subjected to descriptive statistics. When the effects of treatments were significant, mean comparison was performed using least significance differences (LSD) at 5\% probability level.

\section{Results and discussion}

\section{Soil properties}

\section{Soil bulk density and texture}

Soil bulk density (BD) $\left(\mathrm{g} \mathrm{cm}^{-3}\right)$ was affected by soil conservation practices. It ranges from $0.96 \mathrm{~g} \mathrm{~cm}^{-3}$ (physical SWC for 5 years) to $1.10 \mathrm{~g} \mathrm{~cm}^{-3}$ (non-conserved crop land) (Table 1). The lower mean $\mathrm{BD}$ value under integrated measures for 5 years might be the subsequent effects of reduced soil loss and crop residue through erosion; and addition of organic matter from plants. Similar results were reported by (Gebiresilassie et al. 2013; Dulo et al. 2017; Solomon et al. 2017 and Worku 2017) who indicated lower mean soil BD value in conserved farms than non-treated cultivated lands. Data regarding particle size distribution revealed dominantly clay textural class which implying that SWC practices (management) do not alter the soil texture. The result agrees with the finding of Lemma et al. (2017) who reported non-significant difference in texture due to SWC management practices.

\section{Soil pH}

Soil $\mathrm{pH}$ among conservation practices varied between 5.87 and 6.60. The minimum and maximum $\mathrm{pH}$ value was recorded from non-conserved land and integrated SWC practices for 5 years, respectively (Table 1). From the result it was observed that the soil pH has shown an increasing trend with age and integration of SWC practices (Fig. 2). These might be associated to the decrease of the loss of soil organic matter and exchangeable bases through soil erosion and runoff; and thereby increase soil $\mathrm{pH}$. Pearson correlation matrix (Table 2) also showed that organic carbon was positively and significantly associated with soil $\mathrm{pH}\left(\mathrm{r}=0.73^{* * *}\right)$. The result is in agreement with different scholars who observed lower $\mathrm{pH}$ value

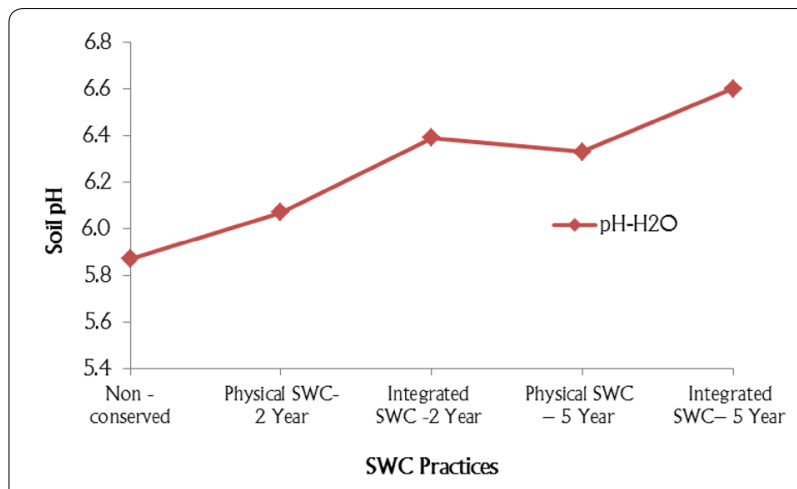

Fig. 2 Effects of SWC practices on soil pH in farm lands of Bashe micro watershed

from the non-conserved cultivated land as compared to conserved farms (Million 2003; Haweni 2015; Worku 2017; Solomon et al. 2017) that was attributed to the high soil erosion, loss of basic nutrients, relatively lower base saturation percentage and lower soil organic matter content. For instance, Worku (2017) reported that land with stone bund had higher soil $\mathrm{pH}(5.89 \pm 0.038)$ than control $(5.81 \pm 0.043)$. Solomon et al. (2017) also recorded that soil $\mathrm{pH}$ in terraced cultivated land was higher (6.0) compared to non-terraced farm land (5.5).

\section{Soil organic carbon}

SWC practices influenced soil organic carbon (OC) of farm lands. The mean value of soil OC range between 1.34 and $1.74 \%$ in which integrated SWC established for 5 years had the highest value and the minimum was obtained on non-conserved land (Table 1 and Fig. 3). Overall, it was noted that the longer the age of SWC practices and its integration with biological measures, the positive is its impact on soil OC of cultivated lands. This might show that SWC practices have a positive role in improving soil OC. The finding was supported by Million (2003) who reported higher soil OC on land conserved with fanyajuu for 5 years $(2.21 \pm 0.08)$ and 10 years $(2.17 \pm 0.1)$ compared non-conserved sites $(1.96 \pm 0.10)$

Table 1 Selected soil physico-chemical properties as influenced by conservation practices in cultivated lands of Bashe micro-watershed, 2018

\begin{tabular}{|c|c|c|c|c|c|c|c|c|c|}
\hline Conservation practices & $\mathrm{BD}\left(\mathrm{g} \mathrm{cm}^{-3}\right)$ & Sand (\%) & Silt (\%) & Clay (\%) & Textural class & $\mathrm{pH}-\mathrm{H}_{2} \mathrm{O}$ & Soil OC (\%) & Soil-OM (\%) & Ava. $\mathrm{P}\left(\mathrm{mg} \mathrm{kg}^{-1}\right)$ \\
\hline Non-conserved & 1.10 & 22.66 & 32.00 & 45.33 & Clay & 5.87 & 1.34 & 2.32 & 8.06 \\
\hline Physical SWC-2 year & 1.07 & 24.00 & 29.00 & 47.00 & Clay & 6.07 & 1.68 & 2.90 & 11.74 \\
\hline Integrated SWC-2 year & 1.06 & 21.33 & 34.33 & 44.33 & Clay & 6.39 & 1.42 & 2.45 & 14.57 \\
\hline Physical SWC-5 year & 1.06 & 21.33 & 40.33 & 38.33 & Clay loam & 6.33 & 1.61 & 2.78 & 20.80 \\
\hline Integrated SWC-5 year & 0.96 & 23.00 & 32.33 & 44.66 & Clay & 6.60 & 1.74 & 3.00 & 25.23 \\
\hline CV (\%) & 3.75 & 17.24 & 15.75 & 14.66 & - & 10.68 & 18.95 & 18.89 & 78.12 \\
\hline
\end{tabular}

CV coefficient of variation 


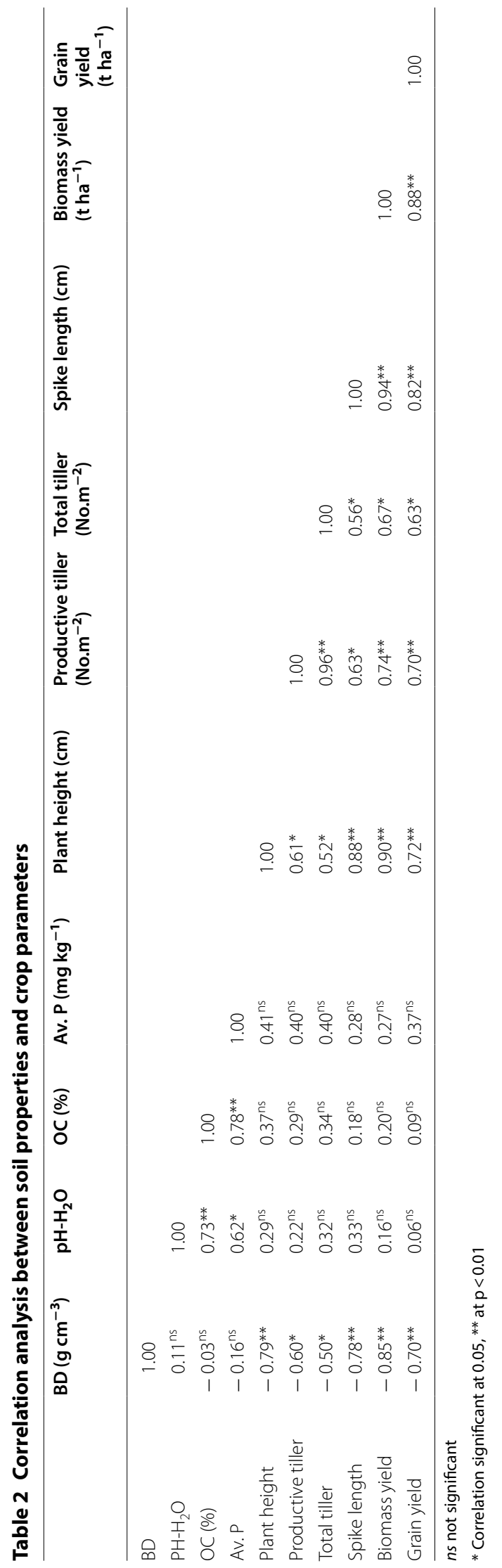




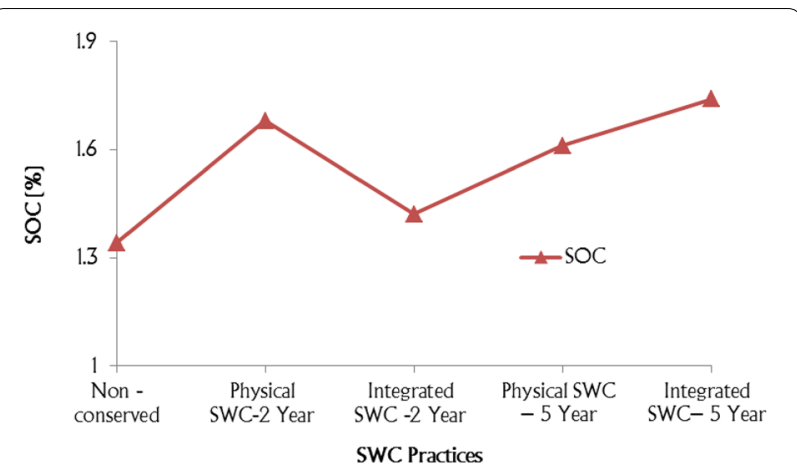

Fig. 3 Effects of SWC practices on soil OC in farm lands of Bashe micro watershed

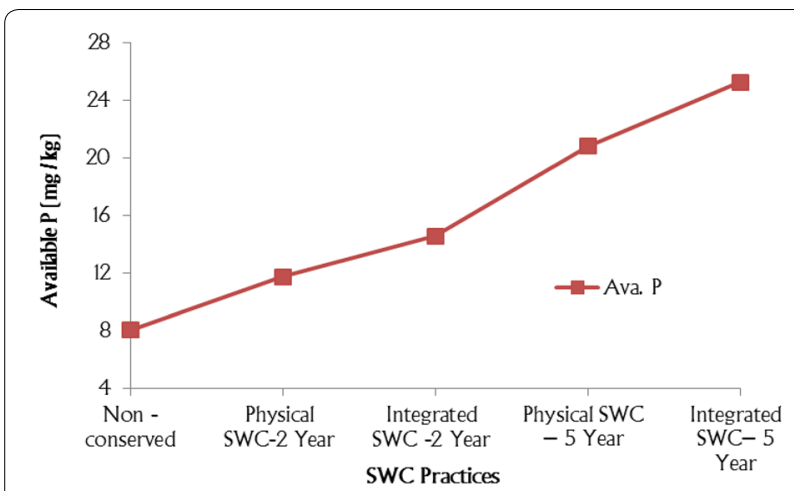

Fig. 4 Effects of SWC practices on available P content in farm lands of Bashe micro watershed

of similar slopes. Other scholars for instance, Demelash and Stahr (2010), Tadele et al. (2011), Dulo et al. (2017), Lemma et al. (2017) and Solomon et al. (2017) also showed a higher value of soil OC on farm lands treated with SWC; and with increasing age of structures (Dulo et al. 2017) when compared to non-conserved land. This implies that SWC measures restore eroded materials on their embankment.

\section{Available phosphorus}

Available P among different SWC practices was highly variable. It varies from 8.06 to $25.23 \mathrm{mg} \mathrm{kg}^{-1}$ (Table 1 and Fig. 4) that was recorded from integrated SWC for 5 years and non-conserved land, respectively. Integrated SWC established for 5 years had 2.13-fold more available $\mathrm{P}$ content than non-cultivated land. The result clearly depicted that the longer the establishment of SWC practices and its integration with biological measures positively influenced available $\mathrm{P}$ content of cultivated lands (Fig. 4). It is clear that changes recorded in soil $\mathrm{pH}$, restoration of soil $\mathrm{OC}$ and maintenance of externally added $\mathrm{P}$ by reducing soil erosion and runoff could result an increased available $\mathrm{P}$ on integrated and aged SWC practices. This is also supported by correlation matrix (Table 2) that showed positive and significant association of available $\mathrm{P}$ with soil $\mathrm{pH}\left(0.62^{*}\right)$ and $\mathrm{OC}$ $\left(0.78^{* *}\right)$. According to Prasad and Power (1997), available $\mathrm{P}$ is more in the soil when soil $\mathrm{pH}$ range is 6.0-6.5. The result was supported by the finding of Demelash and Stahr (2010) who reported that available P was observed to be significantly different in the treated cultivated land than non-treated cultivated lands. Tolera (2011) in addition confirmed that integration of physical and biological measures on cultivated lands resulted higher amount of available $\mathrm{P}$ than un-conserved cultivated lands. According to the author it was due to improved soil organic matter which increases $\mathrm{P}$ and protect from the removal and fixation.

\section{Growth, yield component and yield of wheat Plant height}

Table 3 depicts the effects of SWC practices on selected growth parameters of wheat crop. SWC practices significantly influenced $(\mathrm{p}<0.05)$ plant height of wheat. The tallest plant $(89.9 \mathrm{~cm})$ was attained form integrated SWC with 5 years duration whereas the shortest plant $(67.20 \mathrm{~cm})$ was recorded from non-conserved cultivated land (Fig. 5). The probable reason could be related to the effect of SWC practices on increasing soil moisture availability through increased infiltration and protecting washing away of essential soil nutrients as it was observed in soil analysis result (Table 2). The reduced limitation of water and nutrients allowed luxurious vegetative growth of crops grown on plots with soil bunds, while those grown without soil bund switched to early senescence and maturity due to the possible terminal moisture stress (Abay 2011; Ferede 2018; Teklu et al. 2018).

\section{Total and productive of tiller}

The yield of wheat crop is affected by different factors of which the number of tillers per plant has a vital position. The larger the number of tillers per plot area, the better will be the status of crop, which at the end results increased yield. Tillering capacity of wheat was significantly $(\mathrm{p}<0.05)$ influenced by SWC practices. The total number of tillers per $\mathrm{m}^{2}$ was varying from 482.73 under physical conservation for 5 years to 348.17 on non-conserved cultivated land in which physical SWC for 5 years resulted $38.6 \%$ tillering advantage than non-conserved cultivated lands (Table 3). Data regarding number of productive tillers per $\mathrm{m}^{2}$ showed the maximum value (469.13) that was obtained from integrated conservation for 5 years whereas the minimum (309.87) number was recorded from non-treated farms. In general, tiller formation increases with increasing age of SWC practices; 
Table 3 Growth, yield component and yield of wheat as influenced by conservation practices in cultivated lands of Bashe micro-watershed, 2018

\begin{tabular}{|c|c|c|c|c|c|c|c|c|}
\hline $\begin{array}{l}\text { Conservation } \\
\text { practices }\end{array}$ & $\begin{array}{l}\text { Plant height } \\
\text { (cm) }\end{array}$ & $\begin{array}{l}\text { Total tiller (No. } \\
\mathrm{m}^{-2} \text { ) }\end{array}$ & $\begin{array}{l}\text { Productive } \\
\text { tiller (No. } \\
\mathrm{m}^{-2} \text { ) }\end{array}$ & $\begin{array}{l}\text { Biomass } \\
\text { yield } \\
\left(\mathrm{t} \mathrm{ha}^{-1}\right)\end{array}$ & Straw $\left(\mathrm{t} \mathrm{ha}^{-1}\right)$ & $\begin{array}{l}\text { Spike length } \\
(\mathrm{cm})\end{array}$ & $\begin{array}{l}\text { Grain } \\
\text { yield } \\
\left(\mathrm{t} \mathrm{ha}^{-1}\right)\end{array}$ & $\begin{array}{l}\text { Thousand } \\
\text { seed weight } \\
\text { (g) }\end{array}$ \\
\hline Non-conserved & $67.20 c$ & $348.17 c$ & $309.87 c$ & $5.93 c$ & $3.30 \mathrm{c}$ & $4.20 c$ & $2.47 b$ & $27.56 c$ \\
\hline $\begin{array}{l}\text { Physical SWC-2 } \\
\text { year }\end{array}$ & $72.10 \mathrm{~b}$ & $396.30 \mathrm{bc}$ & $365.40 \mathrm{~b}$ & $6.67 b c$ & $4.16 b$ & $4.66 \mathrm{bc}$ & $2.67 \mathrm{~b}$ & $34.10 \mathrm{~b}$ \\
\hline $\begin{array}{l}\text { Integrated SWC-2 } \\
\text { year }\end{array}$ & $72.56 b$ & $451.87 a b$ & 419.77ab & $7.63 b$ & $4.83 b$ & $5.66 b$ & $2.78 b$ & $36.50 \mathrm{~b}$ \\
\hline $\begin{array}{l}\text { Physical SWC-5 } \\
\text { year }\end{array}$ & $71.33 \mathrm{bc}$ & $482.73 a$ & $464.23 a$ & $7.53 b$ & $4.16 b$ & $5.23 b c$ & $3.33 b$ & $34.60 \mathrm{~b}$ \\
\hline $\begin{array}{l}\text { Integrated SWC-5 } \\
\text { year }\end{array}$ & $89.90 a$ & 476.53a & $469.13 a$ & $11.00 \mathrm{a}$ & $6.73 a$ & $8.56 a$ & $4.27 a$ & 49.73a \\
\hline $\mathrm{LSD}_{0.05}$ & 4.17 & 56.014 & 55.383 & 1.3451 & 0.815 & 1.16 & 0.87 & 2.93 \\
\hline CV (\%) & 3.07 & 7.14 & 7.5 & 9.54 & 9.65 & 11.25 & 15.45 & 4.42 \\
\hline
\end{tabular}

LSD least significant differences, $C V$ coefficient of variation, means followed by the same letters indicates not significantly different at $5 \%$ level of significances, NS non-significant

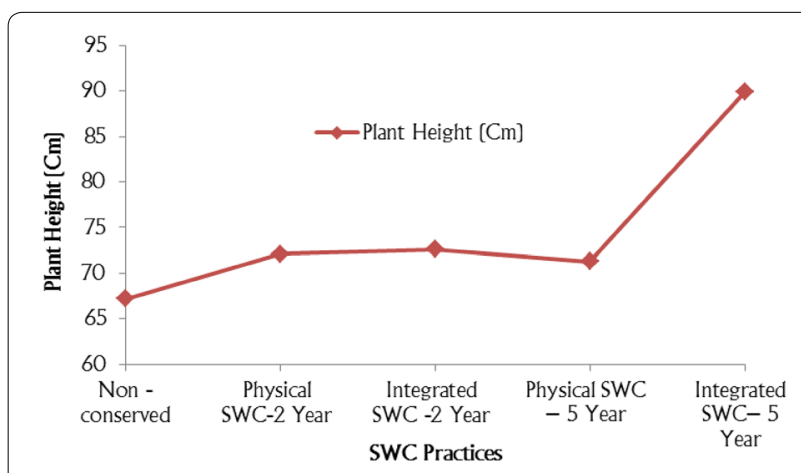

Fig. 5 Effects of SWC practices on plant height of wheat in farm lands of Bashe micro watershed

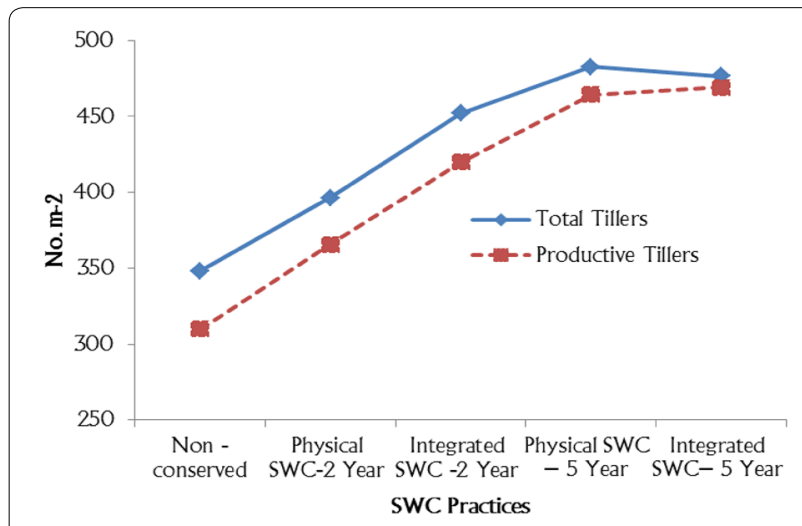

Fig. 6 Effects of SWC practices on tiller formation of wheat in farm lands of Bashe micro watershed and under integrated measures (Fig. 6). This corroborates the findings of Teklu et al. (2018) who reported higher tiller number per plant of wheat grown with soil bund.

\section{Biomass}

The use of SWC practices significantly increased biomass yield of wheat (Table 3). The maximum total biomass from integrated SWC for 5 year was $11 \mathrm{t} \mathrm{ha}^{-1}$ which is 85.5\% more than the minimum from non-conserved farm $\left(5.93 \mathrm{t} \mathrm{ha}^{-1}\right)$. The longer the establishment year of SWC practices and corresponding integration with biological measures has resulted corresponding advantage on biomass yield of wheat (Fig. 7). This might be due to the fact that SWC practices reduced run off loss of nutrients; and improved access of plants to both water and nutrients due to improvements in soil properties such as infiltration rate, moisture retention and nutrient availability. These contributed to increased plant height, tiller production and spike length, finally leading to increased biomass yield as compared to the control. This is also supported by Pearson correlation matrix (Table 2) that showed significant association of biomass with soil BD $\left(-0.85^{* *}\right)$, plant height $\left(0.90^{* *}\right)$, productive tillers per $\mathrm{m}^{2}$ $\left(0.74^{* * *}\right)$ and spike length $\left(0.94^{* * *}\right)$. The result of the present finding on biomass yield agrees well with the result of Teklu et al. (2018) who reported that higher biomass yield of wheat, maize and ground nut crops grown on fields supported by soil bund as a result of better soil moisture retention and supplying of water to the crops. In addition, Ferede (2018) observed $29.2 \%$ and $36.8 \%$ biomass increment on maize due to soil bund, and interaction effects of soil bund and intercropping, respectively. 


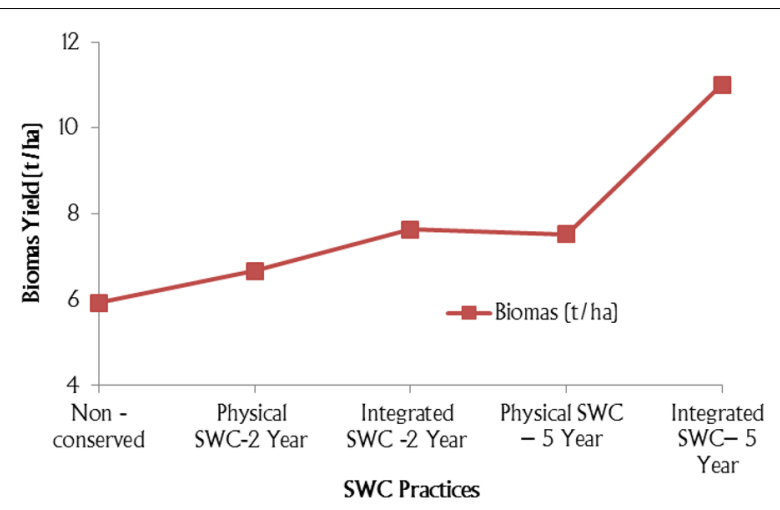

Fig. 7 Effects of SWC practices on biomass yield of wheat in farm lands of Bashe micro watershed

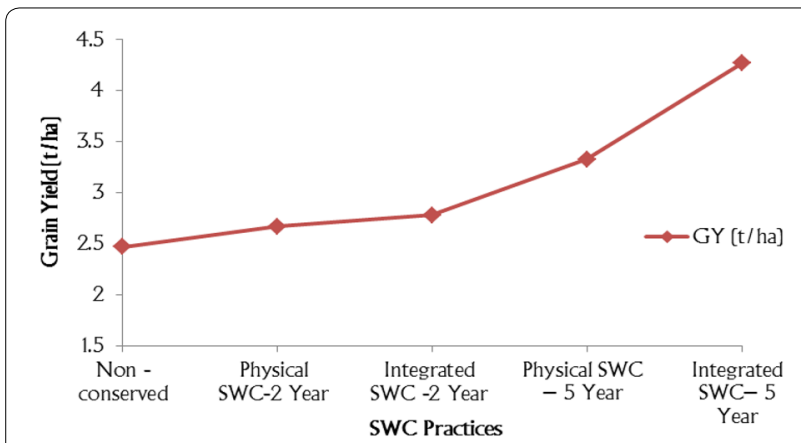

Fig. 8 Effects of SWC practices on grain yield of wheat in farm lands of Bashe micro watershed

Higher sorghum biomass yield on terraced site compared to non-terraced site in Northern Ethiopia was also reported by Alemayehu et al. (2006).

\section{Grain yield}

The end goal of crop production is maximizing yield, which is cumulative function of individual yield components in response to improved seed and management practices. Grain yield of wheat was significantly $(\mathrm{p}<0.05)$ different due to SWC practices that vary between 2.47 $\mathrm{t} \mathrm{ha}^{-1}$ (non-conserved land) and $4.27 \mathrm{t} \mathrm{ha}^{-1}$ (integrated SWC for 5 years) (Table 3). The maximum grain yield was $72.9 \%$ more than the yield obtained from untreated farms. Construction of SWC with time and integration with biological activities result in a successive increase in grain yield of wheat compared to non-conserved plot (Fig. 8). The improvement in grain yield due to SWC practices might be related to the enhanced water availability until grain filling stage, reduced runoff, increased infiltration and enhanced nutrients availability that might give extended time for increased photosynthesis, nutrient uptake and grain filling, and finally resulted in better yield components and grain yield. This is also evidenced by a significant association of grain yield with soil BD $\left(-0.70^{* *}\right)$, biomass yield $\left(0.88^{* *}\right)$ and yield components (Table 2). The results are in accordance with Alemayehu et al. (2006), Abay (2011), Ferede (2018), Teklu et al. (2018), Tugizimana (2015) and Adimassu et al. (2014) who found substantial grain yield increment on lands with SWC measures compared to non-conserved land. Similarly, Eshetu et al. (2016) reported up to $87 \%$ maize grain yield advantage by using fanyajuu than without treatment.

\section{Conclusion}

It is concluded that SWC practices have positive impacts on soil fertility and crop productivity of cultivated lands. From agronomic view point, this is also justified by $72.9 \%$ more grain yield advantage from integrated SWC practices established for 5 years over non-conserved land. This might be attributed to reduced runoff, retained moisture and enhanced nutrients availability during growth time that is leading to improvement of soil properties and grain yield. It is fact that the changes on soil properties and yield become increasing when physical works are integrated with biological practices and with increasing age of establishment. Additionally, stabilizing physical SWC structures by planting multi-purpose grasses/plants would also benefit farmers by providing fodder/fuel. Thus, this study recommends the use of integrated SWC practices. Yet, further studies on other crops yield performance and cost effectiveness of SWC practices are suggested. Furthermore, identification of best grass/plant type that can stabilize the bund and provide added benefits to farmers should be investigated.

\section{Abbreviations}

BD: soil bulk density; OC: organic carbon; OM: organic matter; PSD: soil particle size distribution; SWC: soil and water conservation.

\section{Authors' contributions}

TT collected, analyzed and interpreted the data. FL contributed in advising and drafting the manuscript. Both authors read and approved the final manuscript.

\section{Acknowledgements}

We acknowledge farmers of Bashe micro watershed of Damot Gale District who allowed their land and crops for this study.

\section{Competing interests}

The authors declare that they have no competing interests.

\section{Availability of data and materials}

We declare that the data and materials presented in this manuscript can be made available as per the editorial policy of the journal.

Consent for publication

All data and information are generated and organized by the authors. 
Ethics approval and consent to participate

Not applicable to this manuscript.

\section{Funding}

Not applicable to this manuscript.

\section{Publisher's Note}

Springer Nature remains neutral with regard to jurisdictional claims in published maps and institutional affiliations.

Received: 1 February 2019 Accepted: 20 April 2019

Published online: 30 April 2019

\section{References}

Adimassu Z, Langan S, Johnston R, Mekuria W, Amede T (2017) Impacts of soil and water conservation practices on crop yield, run-off, soil loss and nutrient loss in ethiopia: review and synthesis. Environ Manag 59:87-101

Abay A (2011) Construction of soil conservation structures for improvement of crops and soil productivity in Southern Ethiopia. J Environ Earth Sci 1(1):21-29

Abebayehu A, Awdenegest A (2015) Rill erosion assessment in cultivated lands and farmers perception on soil erosion, a case of Delbo Wogene micro-watershed Southern Ethiopia. J Biol Agric Healthc 5(3):87-115

Adimassu Z, Mekonen K, Yirga C, Kessler A (2014) Effects of soil bunds on runoff, soil and nutrient losses and crop yield in the central highlands of Ethiopia. Land Degrad Dev 25:554-564

Alemayehu M, Yohannes F, Dubale P (2006) Effect of indigenous stone bunding $(K a b)$ on crop yield at Mesobit-Gedeba, North Shoa, Ethiopia. Land Degrad Dev 17:45-54

Amede T (2003) Restoring soil fertility in the highlands of east Africa through participatory research. International Center for Research in Agroforestry. AHI brief No. A1

Anderson JM, Ingram JSI (1993) Tropical soil biology and fertility. A hand book of methods, 2nd edn. CAB International, Wallingford, p 221

Bouyoucos GJ (1951) A recalibration of the hydrometer method for making analysis of the soil. Agron J 43:434-438

CSA (Central Statistics Agency) (2007) Federal Democratic Republic of Ethiopia population census commission summary and statistical, Addis Ababa, Ethiopia

Demelash M, Stahr K (2010) Assessment of integrated soil and water conservation measures on key soil properties in South Gonder, NorthWestern highlands of Ethiopia. J Soil Sci Environ Manag 1(7):164-176

DGWAO (Damot Gale Woreda Agricultural office) (2016) Unpublished base line Data of Damot Gale Woreda, Wolaita Zone, Ethiopia

DGWFED (Damot Gale Woreda Finance and Economic Development) (2016) Unpublished population statistical data and agroecology data of Damot Gale Wolaita Zone, Ethiopia

Dulo H, Feto E, Fisiha G (2017) Effects of soil bund on soil physical and chemical properties in Arsi Negelle woreda, Central Ethiopia. Afr J Environ Sci Technol 11(10):509-516

Eshetu A, Tadele G, Gemechu A, Desalegn M, Alemayhu D (2016) Effects of level Fanya Juu and Fanya Chin structures on grain yield of maize in moisture stress areas of Daro Labu district, West Hararghe Zone, Ethiopia. J Biol Agric Healthc 6(21):94-98

Ferede AJ (2018) Assessing soil bund and haricot bean-maize intercropping effects on productivity of maize at Arjo, Eastern Wollega Zone, Oromia, Ethiopia. Int J Eng Sci Comput 8(11):19313-19325

Fikir A, Nurhussen T, Nyssen J, Atkilt G, Amanuel Z, Mintesinot B, Deckers J, Poesen J (2009) The impacts of watershed management on land use and land cover dynamics in Eastern Tigray (Ethiopia). Resour Conserv Recycl 53:192-198

Gachene C, Kimaru G (2003) Soil fertility and land productivity: a guide for extension workers in eastern Africa. Nairobi, Kenya

Gebiresilassie Y, Amare T, Terefe A, Yitaferaru B, Wolfgramm B, Hurni H (2013) Soil properties and crop yields along the terraces and toposequences of Anjeni watershed, central high lands of Ethiopia. J Agric Sci 5(2):134-144

Haweni H (2015) Effect of soil and water conservation on selected soil characteristics in Dimma Watershed, Central Ethiopia. MSc Thesis, Addis Ababa University, Ethiopia, pp 99
Kebede W (2015) Evaluating watershed management activities of campaign work in Southern Nations, Nationalities and Peoples' Regional State of Ethiopia. Environ Syst Res 4:6. https://doi.org/10.1186/s40068-015-0029

Laekemariam F, Kibret K, Mamo T, Karltun E, Gebrekidan H (2016) Physiographic characteristics of agricultural lands and farmers' soil fertility management practices in Wolaita zone, Southern Ethiopia. Environ Syst Res 5:24

Laekemariam F, Kibret K, Shiferaw H (2018) Potassium (K)-to-magnesium (Mg) ratio, its spatial variability and implications to potential Mg-induced $\mathrm{K}$ deficiency in Nitisols of Southern Ethiopia. Agric Food Secur 7:13

Lemma T, Menfes T, Fantaw Y (2017) Effects of integrating different soil and water conservation measures into hillside area closure on selected soil properties in Hawassa Zuria District, Ethiopia. J Soil Sci Environ Manag 6(10):268-274

Mekuria W, Veldkamp E, Mitiku H, Nyssen J, Muys B, Kindeya G (2006) Effectiveness of enclosures to restore degraded soils as a result of overgrazing in Tigray, Ethiopia. Department of Land Resources Management and Environmental Protection, Mekelle University, Mekelle, Ethiopia. J Arid Environ 69:270-284

Mekuria W, Veldkamp E, Haile M, Nyssen J, Muys B, Gebrehiwot K (2007) Effectiveness of exclosures to restore degraded soils as a result of overgrazing in Tigray, Ethiopia. J Arid Environ 69(2):270-284

Million A (2003) Characterization of indigenous stone bunding (Kab) and its effect on crop yield and soil productivity at Mesobit-Gedba, North Showa Zone of Amhara Region. Master of Science Thesis, Alemaya University, Ethiopia, pp 45-54

MoARD (Ministry of Agriculture and Rural Development) (2005) Guide line for integrated watershed management. MoARD, Addis Ababa

Olsen S, Cole C, Watanable F, Dean L (1954) Estimation of a variable phosphorus in soil by extraction with sodium bicarbonate. USDA Circ 939:1-19

Osman M, Sauerborn P (2001) Soil and water conservation in Ethiopia: experiences and lessons. J Soils Sediments 1(2):117-123

Prasad R, Power JF (1997) Soil fertility management for sustainable agriculture. Lewis Publishers, New York

SAS Institute Inc (2008) SAS/STAT 9.2 user's guide

SNNPRS (South Natation Natationalities People Regional State) (2012) Agricultural bureau of natural resource and environmental protection authority published integrated watershed management planning and implementation, small scale irrigation and water harvesting development and surveyor farmers training manual, Hawassa, Ethiopia

Solomon $\mathrm{H}$, James L, Woldeamilak B (2017) Soil and water conservation effect on soil properties in the Middle Silluh Valley, northern Ethiopia. Int Soil Water Conserv Res 5:231-240

Tadele A, Yihenew GS, Mitiku H, Yamoh C (2011) Effect of soil and water conservation measures on selected soil physical and chemical properties and barely (Hordeum spp.) yield. J Environ Sci Eng 5:1488-1493

Teklu E, Williams TO, Fanuel L (2018) Integrated soil, water and agronomic management effects on crop productivity and selected soil properties in Western Ethiopia. Int Soil Water Conserv Res 6:305-316

Tolera M (2011) Assessing the role of traditional land management practices in improving crop land productivity: the case of Diga Woreda, Oromia

Tugizimana J (2015) Effects of soil and water conservation techniques on soil productivity and bean grain yield in Nyamasheke District, Rwanda. MSc Thesis, Kenyatta University, Kenya, pp 92

Van Reeuwijk L (2002) Procedures for soil analysis, 6th edn, Technical paper 9. Wageningen, The Netherlands

Walie SD, Fisseha G (2016) Perception of farmers toward physical soil and water conservation structures in Wyebla Watershed, Northwest Ethiopia. World J Agric Sci 12(1):57-63

Walkley A, Black A (1934) Estimation of soil organic carbon in by the chromic acid titration method. Soil Sci 37:29-38

Welu G, Solomon T (2015) Perception of local community towards soil and water conservation in the case of Damote Boloso Kebele, Damote Gale Woreda, Wolaita zone. J Biol Agric Healthc 5(11):149-155

Worku H (2017) Impact of physical soil and water conservation structure on selected soil physicochemical properties in Gondar Zuriya Woreda. Resour Environ 7(2):40-48 